male and female specimens that I figured in my ' Rhopalocera Malayana,' as representing Cramer's species, must be really taken to portray Discophora zal, Westw. I cannot subscribe to this somewhat surprising decision, on the following grounds :-

First :-The varietal male specimen which I figured, and which agreed with all male specimens then examined from the Malay peninsula in having the anterior wings unspotted, cannot in any case be considered a distinct "Malayan race," as I have since received specimens from Sungei Ujong with two of the three series of bluish spots described as typical of the Indian form of the species, but which are certainly not constant. But even supposing that the unspotted form was constant and constituted a distinct race, it could not then be taken as representing the $D$. zal (the male of which was unknown to Prof. Westwood when he described that species), as Mr. Moore possesses in his collection a male which he tells me agrees with the markings of the female of that species, and may therefore be considered typical.

Secondly:-The female form which I figured does not agree with the original figure given by Westwood, which possesses a fourth inner row of spots, and also has the two outer series composed of differently-shaped spots.

If, therefore, $D . z a l$ is really specifically distinct from $D$. tullia, as Mr. Moore's male specimen would denote, it certainly cannot be ascribed to my Malay specimens and figures, as stated by Marshall and De Nicéville; and as these figures undoubtedly show variation from the Indian form of $D$. tullia, as understood and figured by them, the course pursued should have been either to agree with me or to describe the Malay form as a new species!! - the last being an alternative that I, at least, am not prepared to take.

\title{
MISCELLANEOUS.
}

Lucilia macellaria infesting Man.

By Frederick Hombert, M.D., F.C.S.

A farmer's wife, thirty-five years of age, was attacked on Monday, September 27, 1875, with a headache and a flushed face. She stayed at work, expecting a malarial chill, an affection prevailing at that time in the neighbourhood. From this time the pains in the region of the frontal cavity at the base of the nose and below the eye, extending to the right ear, increased. At times the pain was 
more severe than at others, but it never entirely left. This pain was described as preventing hearing and breathing, and so excruciating that at intervals, day and night, her cries could be heard at a great distance from the house. Tuesday evening blood-mucus began to run from the right nostril, which was somewhat swollen, the swelling extending on Tuesday over the whole right side of the face. On this day, the fifth of the complaint, four large maggots dropped out of the right nostril. When I was first called to the patient, Monday, October 4, only the right lip and nostril were swollen, the acrid discharge having somewhat blistered the lips below: After each discharge the maggots dropped from the nostril, until the twelfth day; one hundred and forty or more maggots having escaped. The majority of the maggots were three fourths of an inch in length, there being only a few which seemed a line or two shorter; they were of a yellow hue, conical shape, and having attached to one end two horn-like hooks. The patient recovered fully.

Monday, September 18, 1882, I saw a patient in the same neighbourhood as the first, suffering from the same malady. At that time two hundred and eighty maggots had been discharged, and at the close of the illness over three hundred. There was a swelling. on each side of the nose, with a small opening to each. I lanced these openings and more maggots came out.

In the Indian Territory the so-called screw-fly laid its eggs in the nose of man. In 1847 I heard of several deaths of men and children in Texas, near Dallas. The gad-fly was common in the American Bottom forty years ago. It laid its eggs in the noses of cattle and in the ears of horses and deer, but never in the human nose. The fly that I send is about four times as large as the common fly. Head a dark, glistening green; a bronze face, very lively in appearance. Is it the same that they called in Texas or Indian Territory the screw-fly? or is it the gad-fly seeking a new field?

The patient of 1875 is now alive and well. The second case occurred two years ago near Collinsville, in this county, and proved fatal. The third patient above named is getting well. The fourth is reported from Georgia; the patient died.

The first case which I had under my charge was the first which ever occurred here. The eggs must have been deposited in the nose several days before the fifth, the day the maggots dropped out. On the eleventh day all were discharged. I secured live maggots at that time, September 18, 1882. I put soil in an open-mouthed vial and dropped the maggots on it; they crawled in the ground in about five minutes. I covered the opening with white damastis and hoped that the next year the fly would come out of the ground. But on October 6, or the twentieth day, the vial had fourteen living flies. So, reckoning from six days before the pain commenced for the laying of the eggs, to the twelfth day, when the maggot discharged, making eighteen days, and to this adding the twenty days during which the grubs were in the ground, we have thirty-eight 
days from the time the fly laid the eggs until a new generation of flies is produced from them.

You may think I have dwelt too long on these cases; but if you had to stand at the bed and had seen the suffering and despair of the patients and found that the worms were eating them up, you would not think so.

All these cases occurred in the month of September.

Upon this communication Dr. C. V. Riley says that the insect here referred to as attacking the human subject in Illinois, " is the Lucilia macellaria of Fabricius, the injuries of which to different animals are well known in the south and west, where the larva is called the 'screw-worm.' I have repeatedly endearoured to obtain the true parent of this worm. Dr. Humbert's communication is most interesting, but the specimens yet more so, as the flies he forwards are the first that have positively been bred from the larvæ known as ' screwworms,' and they confirm the above determination of the species. The larvæ agree with others which I have from Texas, taken from the root of the ear of a hog which had been bitten by a dog." Proc. U.S. Nat. Mus. Sept. 1883, p. 103.

\section{Fish Mortality in the Gulf of Mexico.} By S. T. WALKER*.

Knowing your interest in every thing connected with fish \&c., I take the liberty of giving you all the facts I have been able to collect in reference to the late mortality among the fishes in Tampa Bay and adjoining coasts. Had I known before I began my cruise of the extent of this mortality and splendid opportunities afforded of collecting specimens of strange and perhaps unknown species, I might have gone better prepared for collecting specimens; but I had only heard a few vague rumours, and I was little prepared for any thing further than a collection of facts in regard to the matter.

On leaving Clear Water, November 20, I sailed south through Boca Ceiga Bay, and encountered the first dead fish floating on the water near Bird Key, a little south-east of Pass A'Trilla. These were mullet, and as we progressed to the south and east I began to encounter toad-fish, eels, puff-fish, and cow-fish, in immense numbers, and, on attempting to land on the extreme point of Point Pinellas for the night, I was driven to my boat by the stench of thousands of rotting fish upon the beach. The next morning I went ashore and found the dead fish drifted ashore in countless numbers. The eels appeared most numerous, followed by puff-fish, cow-fish, sailor's choice, and small fish of every shape and variety. After these followed groupers, mangrove snappers, jew-fish, garpike, spade-fish, sting-rays, and sharks. Other varieties, unknown to me, were mixed among these, together with vast numbers of catfish. I saw very few mullet here.

- Letter to Prof. S. F. Baird, 


\section{$2 \mathrm{BHL}$ Biodiversity Heritage Library}

Humbert, Frederick. 1883. "Lucilia macellaria infesting Man." The Annals and magazine of natural history; zoology, botany, and geology 12, 353-355. https://doi.org/10.1080/00222938309459642.

View This Item Online: https://www.biodiversitylibrary.org/item/54294

DOI: https://doi.org/10.1080/00222938309459642

Permalink: https://www.biodiversitylibrary.org/partpdf/53632

\section{Holding Institution}

Smithsonian Libraries

\section{Sponsored by}

Smithsonian

\section{Copyright \& Reuse}

Copyright Status: Public domain. The BHL considers that this work is no longer under copyright protection.

This document was created from content at the Biodiversity Heritage Library, the world's largest open access digital library for biodiversity literature and archives. Visit BHL at https://www.biodiversitylibrary.org. 